\title{
PROFIL PEMECAHAN MASALAH MATEMATIKA SISWA DITINJAU DARI GAYA KOGNITIF FIELD DEPENDENT DAN FIELD INDEPENDENT
}

\author{
Resty Tirta Risani \\ Pendidikan Matematika STKIP PGRI Sidoarjo \\ restytirta4@gmail.com \\ Siti Nuriyatin \\ Pendidikan Matematika STKIP PGRI Sidoarjo \\ sitinuriyatin@gmail.com
}

\begin{abstract}
Abtrak:
Penelitian ini bertujuan untuk mendeskripsikan profil pemecahan masalah matematika siswa ditinjau dari gaya kognitif field dependent dan field independent. Kualitatif deskriptif merupakan jenis dari penelitian ini. Penelitian dilakukan di SMP Negeri 1 Candi. Penentuan subjek berdasarkan hasil soal tes GEFT yang diberikan kepada siswa. Hal ini bertujuan untuk mengelompokkan tipe gaya kognitif siswa. Subjek penelitian ini sebanyak 2 siswa dari kelas VIII-E, yaitu 1 siswa dengan gaya kognitif field independent (FI) dengan skor hasil tes GEFT antara 13 sampai dengan 15 dan 1 siswa dengan gaya kognitif field dependent (FD) dengan skor hasil tes GEFT antara 4 sampai dengan 6 . Tes pemecahan masalah aritmatika sosial diberikan untuk melihat pemecahan masalah matematika subjek dalam menyelesaikan masalah. Hasil penelitian menunjukkan perbedaan signifikan kedua subjek pada tahap melaksanakan rencana penyelesaian, yaitu subjek FI lebih mampu melaksanakan rencana penyelesaian dengan mengaitkan informasi soal dan rumus yang digunakan untuk menyeleseaikannya dibandingkan subjek FD. Subjek FI menunjukkan pemahaman yang baik dalam menentukan setiap hasil akhir perhitungan bentuk pecahan dan desimal bila dibandingkan dengan subjek field dependent.

Kata Kunci: Profil Pemecahan Masalah, Gaya Kognitif Field Dependent, Gaya Kognitif Field Independent.
\end{abstract}

\begin{abstract}
:
This study aims to describe the profile of students' mathematical problem solving in terms of the field dependent and field independent cognitive styles. This type of research was descriptive qualitative research. The study was conducted at SMP Negeri 1 Candi in 2018/2019 school year. Determination of the subject based on the acquisition of the results of GEFT (Group Embedded Figures Test) test questions given to students in order to classify students' cognitive style types. The subjects used in this study were 2 students taken from class VIII-E, which 1 students are with independent field cognitive style with GEFT test scores between 13 and 15 and 1 students are with field dependent cognitive style with a score of GEFT test results between 4 up to 6 . The social arithmetic problem solving test is given to see the problem solving of the subject in solving problems. The results showed a significant difference between the two subjects in implementing the completion plan, namely the field independent subjects were able to carry out the completion plan better by linking information from the questions and formulas used for determine the answer when compared with the field dependent subject. In addition, the
\end{abstract}


independent field subject showed a good understanding to determine each final result of the calculation of fractional and decimal forms when compared to the field dependent subject.

Keywords: Problem Solving Profile, Field Independent Cognitive Styles, Field Dependent Cognitive Styles.

\section{PENDAHULUAN}

Penekanan tujuan pembelajaran matematika yaitu pemecahan masalah matematika. Pemecahan bukan hanya sebagai tujuan belajar dari matematika, tetapi juga sebagai alat utama melakukan proses belajar (NCTM, 2000). Hal itu dikarenakan dengan belajar memecahkan masalah siswa akan dapat berlatih mengintegrasikan konsep, teorema, mengembangkan kemampuan untuk membangun ide dan keterampilan yang dipelajari. Terdapat empat tahapan memecahkan masalah, yaitu memahami masalah (understanding the problem), membuat rencana penyelesaian (devising a plan), melaksanaka $\mathrm{n}$ rencana penyelesaian (carrying out the plan), dan memeriksa kembali (looking back) (Polya, 1973). Berikut merupakan indikator pemecahan masalah Polya dalam penelitian ini:

\begin{tabular}{|c|c|}
\hline $\begin{array}{l}\text { Pemecahan Masalah Menurut } \\
\text { Polya }\end{array}$ & Indikator \\
\hline \multirow{3}{*}{ 1. Memahami Masalah } & $\begin{array}{l}\text { 1.1 Menyatakan apa yang diketahui dan yang ditanyakan dari } \\
\text { masalah }\end{array}$ \\
\hline & $\begin{array}{l}\text { 1.2 Melakukan pengulanagn terhadap informasi yang baru } \\
\text { diterima }\end{array}$ \\
\hline & $\begin{array}{l}1.3 \text { mendeskripsikan kembali permasalahan dengan bahasa } \\
\text { sendiri }\end{array}$ \\
\hline \multirow{2}{*}{$\begin{array}{l}\text { 2. Menyusun Rencana } \\
\text { Penyelesaian }\end{array}$} & $\begin{array}{l}\text { 2.1 Menentukan konsep, rumus, atau pengetahuan lain yang } \\
\text { telah dikuasai untuk menyusun rencana penyelesaian }\end{array}$ \\
\hline & $\begin{array}{l}\text { 2.2 Mengaitkan informasi soal dengan pengetahuan yang } \\
\text { dikuasai }\end{array}$ \\
\hline \multirow{2}{*}{$\begin{array}{l}\text { 3. Melaksanakan Rencana } \\
\text { Penyelesaian }\end{array}$} & 3.1 Melaksanakan rencana penyelesaian \\
\hline & 3.2 Berargumen logis dalam menlaksanakan penyelesaian \\
\hline \multirow[b]{2}{*}{ 4. Memeriksa Kembali } & $\begin{array}{l}\text { 4.1 Mengingat penyelesaian yang dilakukan, inti permasalahan, } \\
\text { atau pengetahuan yang diketahui }\end{array}$ \\
\hline & $\begin{array}{l}\text { 4.2 Mengingat kembali kebenaran jawaban dengan cara } \\
\text { mengaitkan inti permasalahan pada soal dan penyelesaian yang } \\
\text { telah dilakukan. }\end{array}$ \\
\hline
\end{tabular}

Setiap orang mempunyai cara masing-masing dalam memecahkan masalah. Cara menyusun, mengolah informasi, dan pengalaman yang merupakan perbedaan yang menetap dan dikenal senagai gaya kognitif (Puspita, 2016, hal. 19). Terdapat berbagai gaya kognitif, diantaranya yaitu gaya kognitif field dependent dan field independent. Perbedaan keduanya yaitu pada bagian bagaimana melihat suatu permasalahan. Individu dengan gaya kognitif field independent akan tetap fokus dan tidak mudah terpengaruh lingkungan, sedangkan individu dengan gaya kognitif field dependent 
mudah terpengaruh dengan lingkungan sehingga mengakibatkan kurangnya fokus atau konsentrasi dalam menerima pembelajaran. Individu dengan kognitif field dependent juga memerlukan petunjuk atau bimbingan secara ekstra agar mendapatkan hasil yang baik, berbeda dengan individu dengan gaya kognitif field independent yang hanya diberi kebebasan dalam belajar, dan diberikan sedikit bimbingan (Desmita, 2011).

Materi aritmatika sosial merupakan materi yang erat kaitannya dengan lingkungan siswa sehingga penggunaannya banyak ditemukan dalam masalah sehari-hari dan merupakan materi yang memungkinkan dapat memunculkan masalah sehari-hari (Fauziah, 2016). Berdasarkan pendapat tersebut peneliti memilih materi aritmatika sosial karena memiliki banyak pengaplikasian dalam kehidupan sehari-hari sehingga sangat memungkinkan untuk digunakan sebagai pemecahan masalah. Dari uraian diatas maka tujuan penelitian ini adalah untuk mendeskripsikan profil pemecahan masalah matematika siswa ditinjau dari gaya kognitif field dependent dan field independent.

\section{METODE}

Penelitian ini adalah penelitian kualitatif deskriptif karena bertujuan untuk mendeskripsikan profil pemecahan masalah matematika pada siswa ditinjau dari gaya kognitif field dependent dan field independent. Penelitian dilakukan di SMP Negeri 1 Candi dengan penentuan subjek berdasarkan perolehan hasil soal tes GEFT (Group Embedded Figures Test) yang diberikan kepada siswa. Hal ini bertujuan untuk mengelompokkan gaya kognitif siswa. Subjek yang digunakan dalam penelitian ini adalah 2 siswa yang diambil dari kelas VIII-E, yaitu 1 siswa dengan gaya kognitif field independent dengan skor hasil tes GEFT antara 13 sampai dengan 15 dan 1 siswa dengan gaya kognitif field dependent dengan skor hasil tes GEFT antara 4 sampai dengan 6. Pengumpulan data pada penelitian ini dilakukan dengan menggunakan metode tes dengan think aloud dan introspektif. Instrumen penelitian yang digunakan dalam penelitian ini adalah GEFT (Group Embedded Figures Test), tes pemecahan masalah matematika yang terdiri dari 1 soal uraian dengan materi aritmatika sosial dan rekaman video untuk mendukung keabsahan data. Untuk menilai ketepatan (akurasi) salah satu validas i yang bisa digunakan yaitu pantas/ kaya (rich) yaitu deskripsi tebal yang dapat digunakan untuk membuat keputusan dalam hal transferbilitas karena peneliti menjelaskan dengan detail partisipan atau setting studinya. Reduksi data, penyajian data, dan penarikan kesimpulan merupakan tahapan analisis dalam penelitian ini.

\section{HASIL DAN PEMBAHASAN}

Paparan hasil tes pemecahan masalah dengan think aloud dan intospektif oleh subjek FI sebagai berikut: 


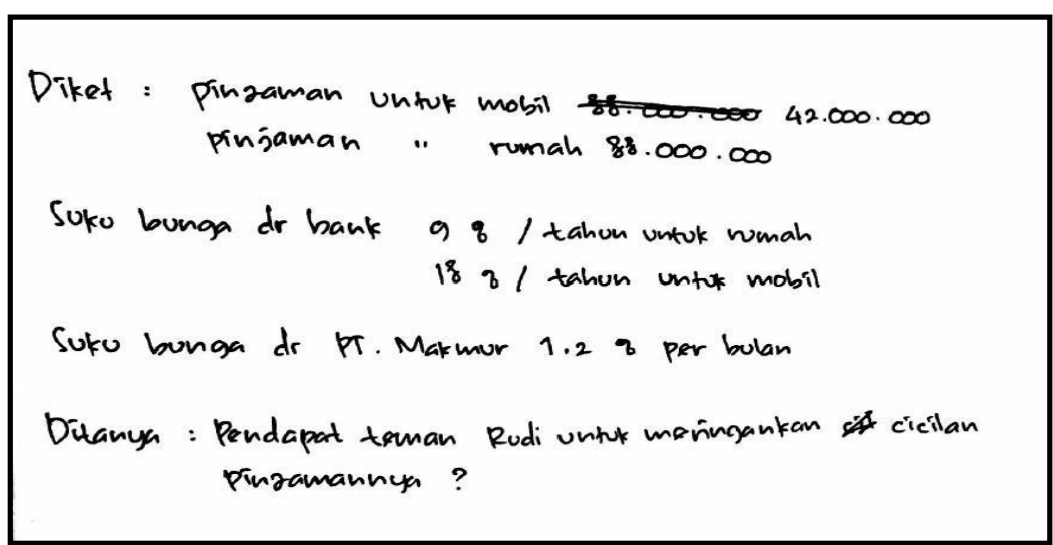

Gambar 1. Jawaban Tes Pemecahan Masalah Subjek Field Independent Bagian 1

Dari gambar 1 dapat dilihat bahwa Subjek FI menuliskan secara terurut yang diketahui dari soal. Berdasarkan hal tersebut dapat dikatakan bahwa subjek FI menyatakan informasi yang diketahui dan yang ditanya pada soal dengan tepat dan sederhana sehingga mudah dipahami. Berdasarkan jawaban tes pemecahan masalah subjek FI dengan think aloud dan introspekt if oleh peneliti diperoleh data, subjek FI melakukan pengulangan membaca terhadap informa $\mathrm{s}$ i yang baru diterimanya sebanyak dua kali. Pada saat mendeskripsikan kembali permasalaha $\mathrm{n}$ ketika think aloud subjek FI mendeskripsikan kembali permasalahn dengan bahasanya sendiri.

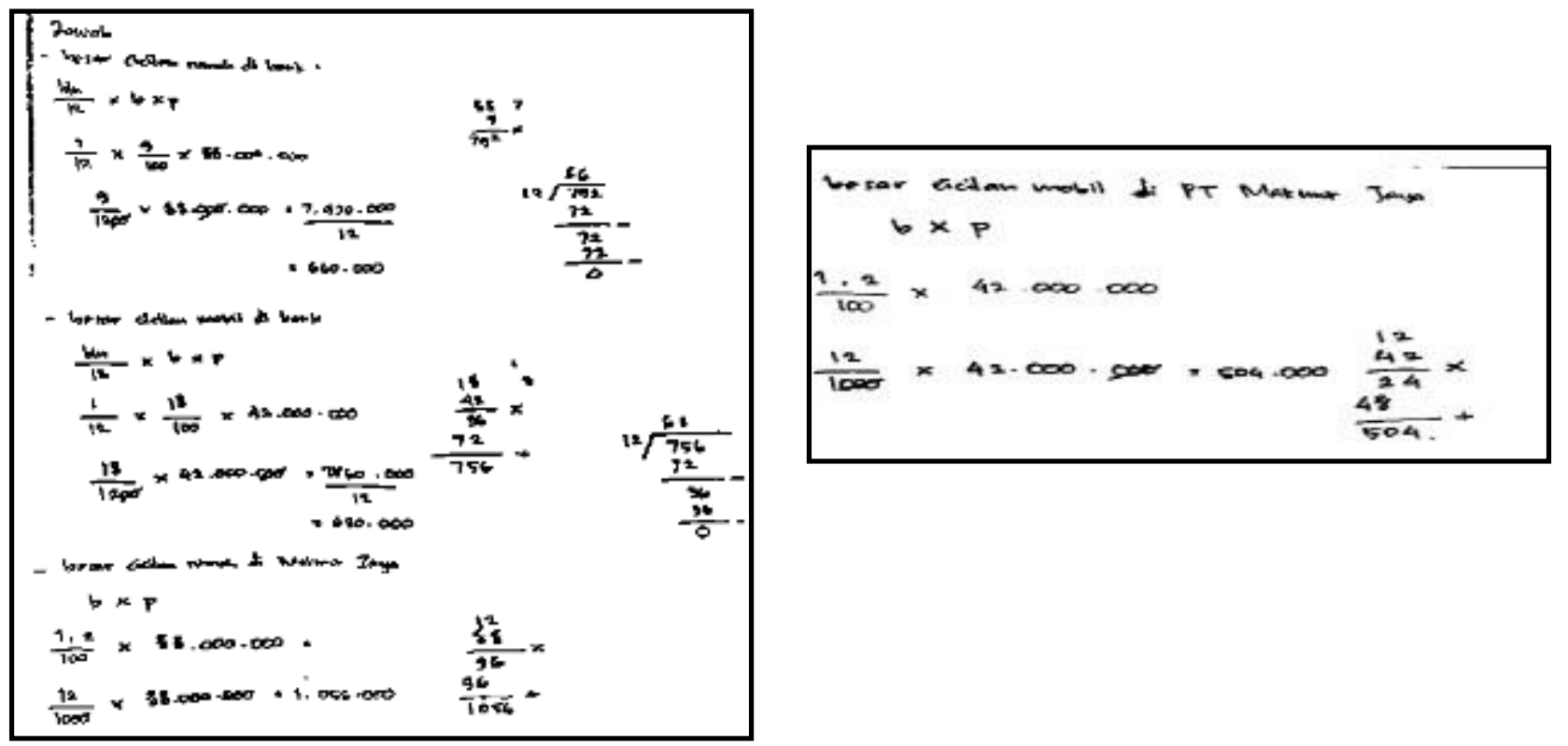

Gambar 2. Jawaban Tes Pemecahan Masalah Subjek Field Independent Bagian 2

Dari gambar 2 dapat dilihat bahwa subyek F1 menuliskan rumus untuk mencari besar cicilan di Bank menggunakan rumus $\frac{b l n}{12} \times b \times p$, sedangkan untuk mencari besar cicilan di PT Makmur Jaya subjek FI menuliskan rumus $b \times p$. Berdasarkan hal tersebut dapat dikatakan bahwa subjek FI menentukan rumus yang sudah dikuasai untuk menentukan rencana penyelesa ia n. Subjek FI mensubtitusikan nilai suku bunga dan pinjaman yang diketahui dari soal ke dalam rumus yang sudah 
ditentukan sebelumnya untuk menyelesaikan soal. Pada akhir kesimpulan jawaban subjek FI memberikan jawaban bahwa pendapat Andi yang paling meringankan Rudi dan memberikan alasan bahwa pendapat Andi yang paling baik karena cicilan mobil di PT Makmur Jaya lebih murah daripada di bank sedangkan cicilan rumah di Bank lebih murah daripada di PT Makmur Jaya. Berdasarkan hal tersebut dapat dikatakan bahwa subjek FI melaksanakan rencana penyelesaian dengan mengaitkan informasi yang diketahui dari soal. Subjek FI juga memberikan argumen yang logis dalam melaksanakan penyelesaian. subjek FI memeriksa kembali jawabannya dengan mengamati ulang secara teliti perhitunga $\mathrm{n}$ yang sudah dilakukan, mengamati penggunaan rumus dan langkah penyelesaian. Berdasarkan deskripsi data hasil tes pemecahan masalah dengan think aloud dan introspekt if oleh peneliti pada subjek FI, tampak bahwa subjek FI memenuhi semua indikator pemecahan masalah matematika siswa.

Paparan hasil tes pemecahan masalah dengan think aloud dan intospektif oleh subjek FD sebagai berikut:

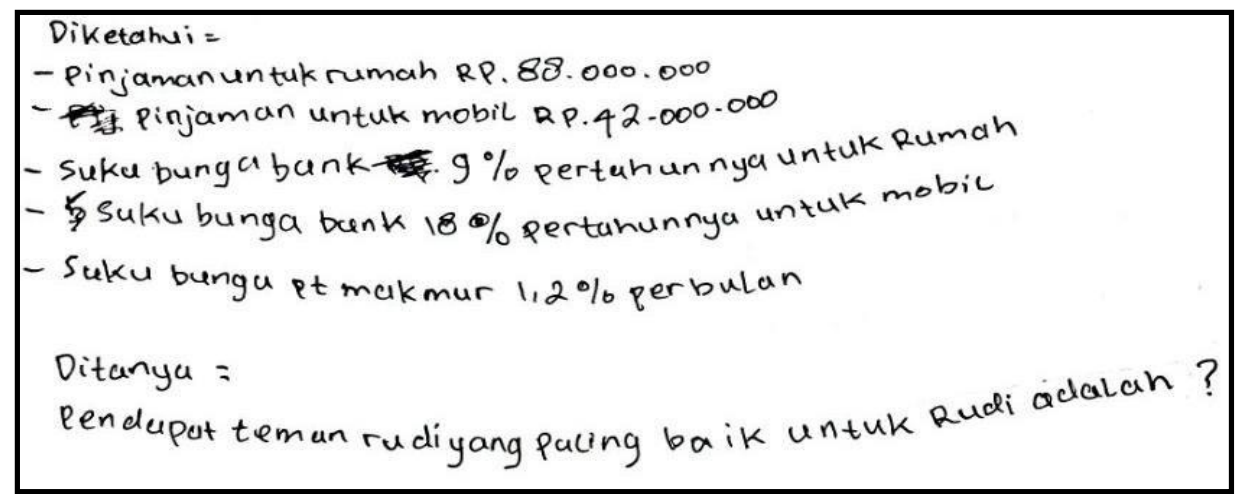

Gambar 3. Jawaban Tes Pemecahan Masalah Field Dependent

Dari gambar 3 dapat dilihat bahwa Subjek FD menuliskan secara terurut yang diketahui dari soal. Berdasarkan hal tersebut dapat dikatakan bahwa subjek ADR menyatakan informasi yang diketahui dan yang ditanya pada soal dengan tepat dan sederhana sehingga mudah dipahami. Berdasarkan jawaban tes pemecahan masalah subjek FD dengan think aloud dan introspektif oleh peneliti diperoleh data, subjek FD melakukan pengulangan membaca terhadap informasi yang baru diterimanya sebanyak tiga kali. Pada saat mendeskripsikan kembali permasalahan ketika think aloud diketahui bahwa subjek FD mendeskripsikan ulang permasalahan dengan bahasanya sendiri. 


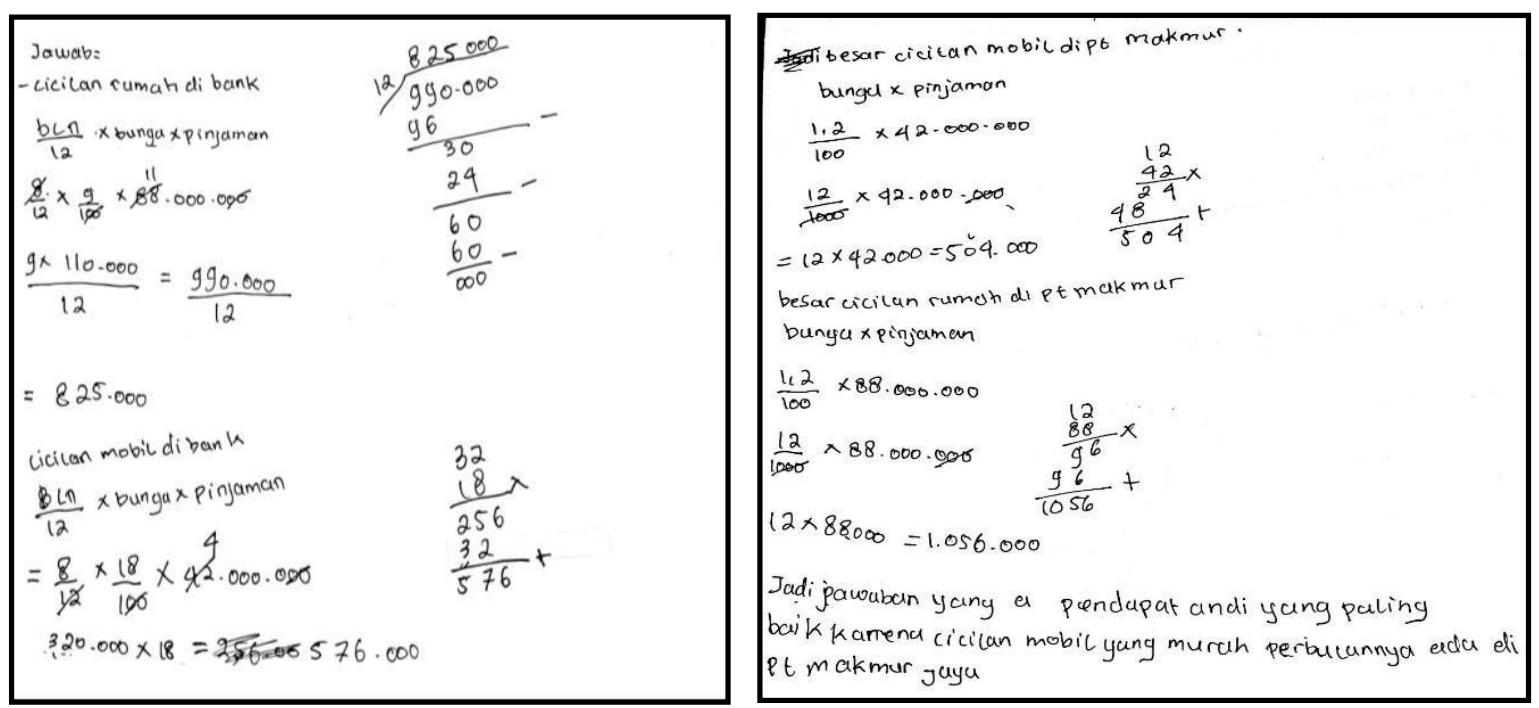

Gambar 4 Jawaban Tes Pemecahan Masalah Subjek Field Dependent Bagian 2

Dari gambar 4 dapat dilihat bahwa subyek FD menuliskan rumus untuj mencari besar cicilan di Bank menggunakan rumus $\frac{b l n}{12} \times$ bunga $\times$ pinjaman, sedangkan untuk mencari besar cicilan di PT Makmur Jaya subjek FD menuliskan rumus bunga $\times$ pinjaman. Berdasarkan hal tersebut dapat dikatakan bahwa subjek FD menentukan rumus yang sudah dikuasai untuk menentukan rencana penyelesaian dan mengaitkan informasi dari soal dengan pengetahuan yang dikuasai. Pada saat mensubstitusi nilai bulan kedalam rumus subjek FD terkecoh dengan keterangan di soal yang menyatakan Rudi mendapat tawaran pinjaman dari PT Makmur Jaya setelah delapan bulan sehingga, subjek menghitung besar cicilan pada Bank untuk setiap delapan bulan. Saat menghitung besar cicilan rumah di Bank, subjek FD membagi delapan dengan delapan puluh delapan yang keduanya adalah pembilang. Saat menghitung besar cicilan mobil di Bank subjek FD juga melakukan kesalahan perhitungan yaitu hasil bagi empat puluh dua dengan dua belas adalah empat. Subjek FD juga tidak bisa menghitung perkalian bentuk desimal. Subjek FD memberikan kesimpulan akhir jawaban yang benar yaitu pendapat Andi yang paling baik tetapi dengan hasil perhitungan yang salah.

Pada transkip think aloud dan introspektif, subjek FD hanya mengecek secara sekilas perhitungan dan langkah penyelesaian sehingga subjek FD tidak mengetahui adanya kesalah pada jawabannya. Berdasarkan hal tersebut maka subjek FD tidak memenuhi semua indikator pemecahan masalah matematika pada tahap memeriksa kembali.

Berdasarkan deskripsi data hasil tes pemecahan masalah dengan think aloud dan introspektif oleh peneliti pada subjek FD, tampak bahwa subjek FD tidak memenuhi semua indikator pemecahan masalah matematika pada tahap melaksanakan rencana penyelesaian dan pada tahap memeriksa kembali. 
Berdasarkan hasil tes pemecahan masalah dengan think aloud dan introspektif oleh peneliti pada dua subjek saat langkah memahami masalah, subjek field independent dan subjek field dependent menyatakan dengan tepat apa yang diketahui dan yang ditanyakan dari masalah. Subjek field independent melakukan pengulan membaca terhadap informasi yang baru diterima sebanyak dua kali, sedangkan subjek field dependent melakukan pengulangan membaca terhadap informasi yang baru diterima sebanyak tiga kali. Pada saat mendeskripsikan kembali subjek field independent maupun subjek field dependent mendeskripsikan kembali permasalah dengan bahasa mereka sendiri.

Pada tahapan menyusun rencana penyelesaian, subyek field independent maupun subyek field dependent menentukan rumus aritmatika sosial yang sudah diketahui dan mengaitkan dengan

informasi dari soal yaitu $\frac{b l n}{12} \times$ bunga $\times$ pinjaman untuk menentukan hasil dari cicilan pinjaman di Bank karena suku Bungan pada Bank dalam bentuk per tahun. Sedangkan untuk menentukan besar cicilan perbuan pada PT Makmur Jaya dengan rumus $b \times p$ karena suku bunga pada PT Makmur Jaya sudah dalam bentuk bulan.

Pada tahap melaksanakan rencana penyelesain terdapat perbedaan proses pengerjaan pada subjek field independent dan subjek field dependent. Subjek field independent melaksanakan rencana penyelesain dengan mengaitkan informasi dari soal dan rumus yang digunakan untuk menentukan jawaban. Selain itu subjek field independent menentukan hasil akhir perhitungan perkalian pada bentuk pecahan dengan tepat serta memberikan alasan yang logis untuk mendukung jawabannya tersebut.

Subjek field dependent kesulitan menentukan hasil akhir perhitungan perkalian pada bentuk pecahan. Subjek FD memberikan kesimpulan akhir jawaban yang benar tetapi dengan hasil perhitungan yang salah. Dapat diketahui bahwa subjek FD salah dalam memaha mi informasi soal, sehingga perhitungan yang dilakukan salah. Pada saat memahami soal subjek FD terkecoh dengan keterangan Rudi yang mendapat tawaran pinjaman dari PT Makmur Jaya setelah delapan bulan sehingga, subjek menghitung besar cicilan pada Bank untuk setiap delapan bulan.

Pada tahap memeriksa kembali, subjek field independent mengingat kembali penyelesaian yang telah dilakukan serta memeriksa kembali dengan teliti kebenaran jawaban. Sedangkan pada subjek field dependent belum memeriksa jawaban secara keseluruhan dengan baik. Subyek hanya memeriksa bagian perhitungan tanpa memeriksa langkah-langkah dalam menyelesaikan masalah.

\section{SIMPULAN}

Berdasarkan hasil penelitian dan pembahasan terhadap deskripsi data pemecahan masalah matematika siswa ditinjau dari gaya kognitif field dependent dan field independent pada materi aritmatika sosial dapat disimpulkan bahwa, siswa dengan gaya kognitif FD dan FI memenuhi semua 
indicator. Pada tahapan memahami masalah dan menyusun rencana penyelesaian. Pada tahapan melaksanakan rencana penyelesaian siswa FI mengaitkan informasi dari soal dan rumus yang akan digunakan untuk menentukan jawaban dan memberikan alasan yang logis untuk mendukung jawabannya. Siswa dengan gaya kognitif FD dalam melaksanakan penyelesaian mengalami kesulitan menentukan hasil akhir perhitungan perkalian pada bentuk pecahan. Selain itu siswa dengan gaya kognitif FD salah dalam memahami informasi soal, sehingga perhitungan yang dilakukan salah. Pada tahap memeriksa kembali siswa FI memeriksa kembali dengan teliti kebenaran jawaban. Sedangkan pada subjek FD belum secara keseluruhan memeriksa jawaban dengan baik.

\section{REFERENSI}

Desmita. (2011). Psikologi Perkembagan Peserta Didik. Bandung: PT Remaja Rosdakarya. Fauziah, L. U. (2016). Penalaran Logis Dalam Memecahkan Masalah Matematika Pokok Bahasan Aritmatika Sosial Pada Siswa Kelas VII SMP Negeri 4 Jember. Jurnal Edukasi, 15-17.

NCTM. (2000). Principles and Standards for School Mathematics. Reston, VA: NCTM. Polya, G. (1973). How To Solve It. Proncetion: Proncetion University Press.

Puspita, A. Y. (2016). Profil Pemecahan Masalah Matematika Siswa Pada Materi SegiempatDitinjau Dari Gaya Kognitif Reflektif Dan Impulsif. MATHEdunesa, 19. 